\title{
Not just another variable: untangling the spatialities of power in social- ecological systems
}

\author{
Micah L. Ingalls ${ }^{1}$
}

\begin{abstract}
Increased attention has been paid to how the spatial dimensions of social-ecological systems are formative in shaping their ability to negotiate change and remain resilient. This paper moves this research further by exploring how diverse forms of power play a crucial role in shaping these spatial dimensions and the production of social-ecological outcomes. Grounding these explorations in a National Protected Area in Lao PDR, this paper explores how power relationships operate through the spatial and temporal domains of complex systems. Findings suggest (at least) four important insights: (1) the exercise of power materializes in policies and programs and becomes written onto the spaces of social-ecological systems through boundary creation, zonation, and other social processes that (re)define spatial meanings; these meanings vary by social actor; (2) policies and programs map out unevenly across space and time as they interact with antecedent social-ecological conditions in ways that preclude linear causal relationships between policy and outcomes; (3) although local in their expression, spatialized disputes in social-ecological systems draw on cross-scalar discourses and networks of power to bolster, undermine, and (de)legitimize competing environmental and social narratives; and (4) however powerful institutions and actor-networks may be, they are never fully hegemonic as they are attenuated by other discourses and operations of power, although these all play out across a highly uneven sociopolitical terrain. Paying greater attention to the spatial and temporal dynamics of power may be much more than a project of introducing yet another variable into the already complex admixture of analytic elements. Rather, by rendering these explicit as objects of analysis, common insights may change entirely or even be overturned.
\end{abstract}

Key Words: conflict; governance; Lao PDR; protected area; social-ecological systems; spatial resiliences

\section{INTRODUCTION}

Conceptualizing social and ecological variables in complex systems as conjoined elements within a larger, social-ecological complex has been particularly productive in shaping the ways we understand dynamic processes within real-world systems. By focusing attention on how these social-ecological systems negotiate change processes and selforganize following disturbance, and the ways in which key system elements are retained, lost, or modified, we have gained important insights into how to manage complex systems despite substantial uncertainty and unpredictability (Folke 2006, Nelson et al. 2007). Understanding complex systems and applying this understanding to addressing real-world problems require that abstract principles be grounded in particular systems - systems that are necessarily bounded in space and time. In so doing, we are reminded that social-ecological systems are geographic objects. In itself, this observation is not surprising. It does, however, open up vast possibilities for exploring how key elements of social-ecological systems are rooted in, and map onto, space and time and the implications of these space-time dynamics for system functioning. Recognizing the ineluctability of space-time in social-ecological systems, recent scholarship has begun to explore the concept of spatial resilience (e.g., Cumming 2011, Allen et al. 2016, Cumming et al. 2016). Spatial resilience focuses on the role of spatial variation and temporal change within complex systems and may be defined as "the ways in which spatial variationincluding such things as spatial location, context, connectivity, and dispersal - influences (or is influenced by) the resilience of a social-ecological system" (Cumming 2011:3). Internal elements of interest to spatial resilience include the spatial arrangement of system components, spatial variation in internal phases (e.g., succession), and the size, shape, number, and character of boundaries. External elements include context, connectivity with exogenous systems, and processes, spatially driven feedbacks, and subsidies.

Although these internal and external elements in spatial resilience function between systems at the same scalar level, evidence suggests that cross-scale dynamics between higher and lower organizational units play a particularly formative role in shaping the spatial resilience of systems, including the ways in which resources and risks are distributed between scales (Adger et al. 2006, Nelson et al. 2007). Along the social dimension, cross-scale interactions between institutional structures and the agency of local people play a central role in the production of socialecological outcomes across space and time (Carpenter and Brock 2004, Pain and Levine 2012). These cross-scale interactions may either support or undermine the ability of local systems to selforganize in response to disturbance events. Given this, a complex systems perspective suggests that the degree to which management is decentralized-giving greater decision-making control to local system managers - may play a particularly important role in conditioning social-ecological dynamics and the resilience of local systems, for example, by facilitating tighter coupling between ecological changes and social responses (Cumming 2011). Furthermore, the processes through which these dynamics play out - the degree to which these interactions are equitable and participatory-may either undermine or strengthen trust between local managers and larger social institutions such as those of state resource managers (Lebel et al. 2006, Nelson et al. 2007). These cross-scale dynamic processes are 
necessarily spatial in their operation and relate closely to questions of legitimacy, solidarity, and justice (Adger 2001, Okereke 2006, Ingalls and Stedman 2016).

Given the dominance of human influence in almost all socialecological systems, interrogating these social dimensions is a central concern (Bolliger et al. 2005, Barrett and Constas 2014). Importantly, the social processes that shape social-ecological systems play out across an unequal field of power wherein the resources available for shaping social-ecological outcomes are distributed differentially, as are their risks (Escobar 1998, Watts 2009, Ingalls and Stedman 2016). Insofar as these dynamics function across spatially situated channels and networks and distribute resources and risks across space and through time (Adger 2001), power in social-ecological systems may be interrogated explicitly with reference to its spatial and temporal dimensions. This paper thus focuses attention specifically on how power is active in shaping the space-time dimensions of complex systems' processes and outcomes. This kind of analysis, I suggest, may be much more than a project of introducing yet another variable into the already complex admixture of multivariate social-ecological systems analysis. Rather, explicitly incorporating questions of power into systems analysis has the potential not only to enhance analytic clarity but may even surprise us, overturning the sorts of findings that might otherwise be produced (Massey 1999).

Power has, of course, a multiplicity of meanings and analytic applications. Perhaps the most obvious way of thinking about power is as dominance, located primarily in the apparatuses of the state or social actors bearing its delegated authority and in which force, violence, and coercion are strongly implied. Such a conceptualization, however, tends to limit attention to the formal apparatus of society, its institutions, and explicit policies. Cognizant of this conceptualization of power-but also elaborating on and departing from it-I here employ a Foucaultian view that emphasizes the multiplicity of power within and across society and its overlapping, fluid, and negotiated nature (Foucualt 1982, 2000). Such a view of power allows us to move beyond an analysis of formal institutions and legal codification to interrogate their subtext and so better to understand the full scope of their influence. It also allows us to focus attention not only on how power may be destructive and exclusionary, but also how it is generative, creative, and productive.

As I have said, these abstractions are best concretized in the complexities of real-world systems. This paper, therefore, presents a spatially explicit interrogation of power relationships within a largely forested social-ecological system in and around Xe Pian National Protected Area (NPA) in the Lao People's Democratic Republic (Lao PDR, or Laos) along the Laos-Cambodian border in Southeast Asia (Fig. 1), exploring some of the ways in which the overlapping spatialities of power within this system have been produced and legitimized, and, in their operation, function to shape the resilience of the system to change.

In this analysis, I will focus on four interrelated thematic emphases. The first of these involves the ways in which power maps onto space, or spatializes, within complex systems. This occurs through a number of different mechanisms such as the creation of administrative or managerial spaces, processes of boundary formation, spatial classification and zonation, tenure regimes, and spatially situated resource claims as well as the particular and socially differentiated meanings that these spatializations carry. Second, I will emphasize the role played by antecedent social-ecological conditions in the production of these spatializations and the ways in which these contextual factors facilitate or impede particular system processes. Third, I will focus on the ways in which discourses of power and knowledge claims at higher scales intersect with local social disputes and power dynamics, and the ways in which local actors draw on these to (de)legitimize contested claims. Finally, while recognizing the highly uneven social landscape of power, I will emphasize the ways in which power is attenuated, shaped, and fragmented not only laterally by competing social institutions, but also vertically by the agential action of local communities.

Fig. 1. Xe Pian NPA forest types and geographic context

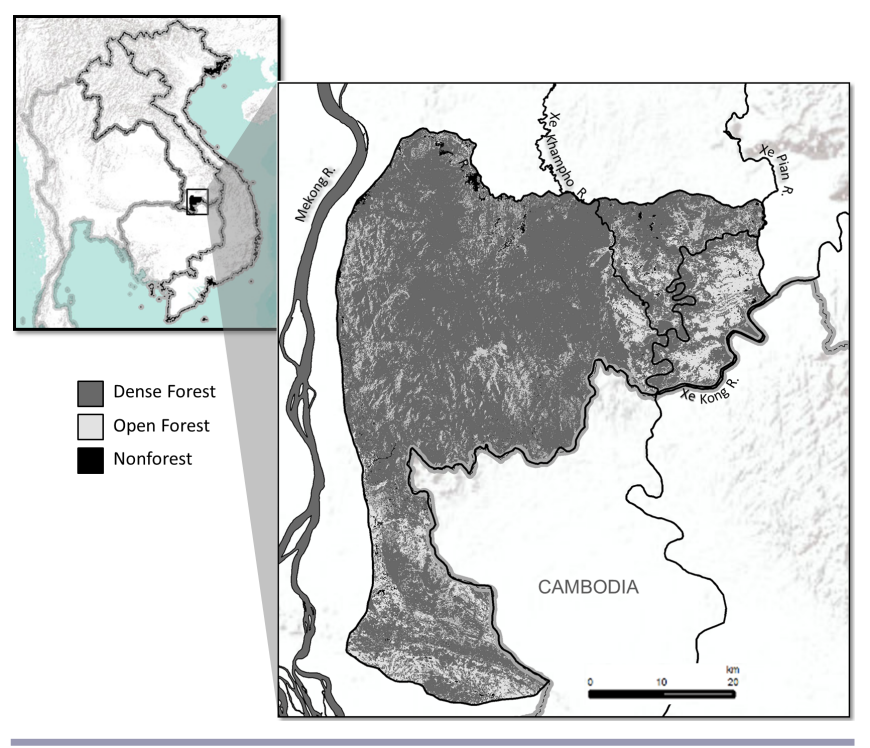

\section{RESEARCH SETTING AND METHODS}

Xe Pian NPA was established by decree of the Prime Minister of Laos in October 1993. Comprising of approximately $2,600 \mathrm{~km}^{2}$ of semievergreen and dry dipterocarp forest types, Xe Pian NPA has been a historically significant habitat for numerous globally important populations of birds and mammals. Biodiversity surveys carried out in 1993 found more than 350 species of birds, including at least eight bird species of global conservation significance (Duckworth et al. 1993). In addition to historic populations of Asian elephant (Elephas maximus), large cats (Panthera spp.), dhole (Cuon alpines), Asiatic black bear (Ursus tibetanus), sun bear (Helarctos malayanus) (Scotson 2012), banteng (Bos javanicus) (Steinmetz 2004), and Irrawady river dolphins (Orcaella brevirostris) (Baird 1997), Xe Pian NPA was also considered to harbor the largest known population of gibbon (Nomascus spp. and Hyloblates spp.) in the world (Timmins et al. 1993, Duckworth et al. 1993).

Xe Pian NPA is also a space inhabited and used by local human communities, including both a permanent population within the NPA as well as seasonal migrants. In total, more than 10,000 
individuals depend on the NPA for a variety of purposes, exhibiting a high degree of natural resource dependency that varies by community: some households purchase as little as 3\% of their consumable resources (World Wide Fund for Nature (WWF) 2013). Local communities utilize a wide diversity of species for food, fibers, medicines, and marketed products. Baird (1997), for example, estimated that some communities derived 40$90 \%$ of their protein from local aquatic resources. Ingalls and Luangsackda (2009) identified more than 250 species of plants and animals used by local communities along the northwestern extremity of the NPA, a finding similar to that of Elkington et al. (2014) in the NPA's northeast. Malva nut (Scaphium macropodium), berberine vine (Coscinium usitatum), resins from dipterocarp species, and semidomestic varieties of cardamom (Amomum villosum) are all commercially significant species that contribute to household incomes, particularly for poorer households.

Alongside a high degree of resource dependency lies persistent poverty. In 2015, 27.6\% of families around Xe Pian fell below the national poverty line, and in some villages, poverty rates at the household level exceeded 53\% (Lao Statistics Bureau (LSB) 2016). Community surveys carried out in 2012 indicated that $75 \%$ of households reported food insufficiency (defined as rice shortage) ranging from 3 to 10 months of the year (WWF 2013). Food insecurity generally relates to a low degree of land holding amongst local communities, with the majority cultivating less than 1 ha. Due to the high degree of endemic poverty and food insecurity, as well as anticipation of increased flooding and heat stress under changing climate conditions (Meynell et al. 2014), Xe Pian NPA is considered to be a high-risk area of priority for Lao PDR, a country more generally considered to be highly vulnerable to climate risks (Global Facility for Disaster Reduction and Recovery (GFDRR) 2011). These climate vulnerabilities, together with intractable issues of poverty and the rapid and severe decline in species diversity and abundance (e.g., Steinmetz 2004, Scotson 2012), presage a number of problems for system functioning into the future and lend urgency to the need for revised approaches for navigating social-ecological change.

Since its inception in 1993, Xe Pian NPA has attracted multiple and somewhat overlapping conservation and development projects, including the Lao-Swedish Forestry Cooperation Program (LSFCP), a number of projects under the WWF, the Global Association for People and Environment (GAPE), the Asian Development Bank-funded Biodiversity Corridors Initiative (BCI), and, most recently, a Reduced Emissions from Deforestation and Forest Degradation (REDD+) project supported by WWF-Austria. These programs and the discourses surrounding them form core objects of my analysis here. Understanding the processes of power and their social-ecological outcomes involves not only the assessment of what policies and programs say they will do, but also how they work out in practice (see Arts and Buizer 2009). The research approach thus maintained an analytic dualism between these dimensions, employing both the analysis of policies and project documentation (project reports, management plans, etc.), as well as interviews with government officials at national, provincial, and district levels between 2012 and $2017(n=26)$, international and national experts $(n=13)$, and the communities in the NPA and surrounding it. Engagement with local communities primarily took the form of focal group discussion $(n=272$ individuals in nine villages) between 2012 and 2015, supplemented by local key person interviews $(n=16)$. Focal group engagements involved semistructured discussions, participatory resource mapping, and community-led field surveys to explore local and state management arrangements, historical processes of zoning and land-use planning, the creation of village and NPA boundaries, patterns of resource use, and norms of access. Wherever possible, interviews and focal group discussions were audiorecorded in Lao language using a handheld recording device and transcribed by the author. Data analysis involved review and selective coding of transcripts and handwritten notes, concept mapping, and identification of key elements and processes reported by participants. In order to situate these local analyses within broader institutional processes and to analyze relevant policy discourses, I also participated in 23 national dialogs and working groups in Lao PDR.

In the sections that follow, I will trace the evolving dynamics of space, time, and power within this social-ecological system in a loosely chronological fashion, asking (1) What relationships of power manifest within the spaces of the social-ecological system - surrounding what objects and between what interests - and how do they interact with one another? (2) What discourses are employed to (de)legitimize these spatializations of power? and (3) With what implications for social-ecological system processes and outcomes?

\section{FORTRESS CONSERVATION AND THE ORIGINS OF THE NPA}

In the late 1980s and early 1990s, when timber exports had become an increasingly important source of foreign exchange in Laos and the principal source of revenue for the state treasury (Ireson and Ireson 1991), the government of Laos enacted two closely related measures aimed at limiting environmental degradation and ensuring a sustainable forest resource base. The first of these was Laos's decision to participate in the multilateral Tropical Forest Action Plan, a plan aimed at professionalizing the forest industry by clarifying and bolstering rules of (largely state-based) forest governance, and limiting unauthorized and inefficient use of forest resources (Guttal 2011). The second measure, that which would result in the creation of Xe Pian NPA, was a broad-based exploratory assessment for a system of national nature reserves, carried out largely by foreign conservation scientists beginning in 1988 with support from the International Union for the Conservation of Nature (IUCN) and the LSFCP. To specify the appropriate local objects of this intervention and map out the nature reserve system, Berkmüller et al. (1995) drew on supralocal spatializations, most notably MacKinnon and MacKinnon's (1986) assessment of the Indomalayan realm, to identify areas proportionately representing regional biogeographic types (Fig. $2 a$ ). In order to localize these regional spatial categories, planners took into consideration the pre-existing network of largely unmanaged forest reserves created under the French administration of the former Kingdom of Laos, and then screened these through additional selection criteria including the presence of key species of global conservation interest, large undisturbed tracts of forest with $75 \%$ of original forest cover (over a minimum of $500 \mathrm{~km}^{2}$ ), and the degree of threat to these attributes. These national assessments recommended a total of 68 forested areas for gazettement in the national reserve system 
(Salter and Phanthavong 1989). Scientific proposals did not directly translate into the final reserve areas. Rather, the areas of proposed reserves were weighed against other concerns and interests of state authorities whose commercial and developmentalist agendas (such as land concessions and timber interests) might be put at risk (interviews, 2014-2015). The spaces slated for conservation emerged from these spatial negotiations (Fig. 2b). Two areas, Xe Pian and Dong Kalo, would later be amalgamated into the Xe Pian forest reserve in 1993. A particularly intensive on-the-ground survey effort was carried out between 1992 and 1993 for Xe Pian and Dong Kalo in order to further characterize key conservation values and risks to these. Local livelihood activities, especially hunting, fishing, and subsistence agriculture - typically described as "encroachment" and "degradation"-alongside commercial logging were identified as the primary risks to be managed for to secure environmental values. Timmins et al. (1993:6) concluded that Xe Pian was "relatively pristine" but "will be irrecoverably degraded without immediate measures to curb human use."

Fig. 2. Lao PDR NPA system with biogeographic zones. Sources: zones adapted from MacKinnon and MacKinnon (1986), Salter and Phanthavong (1989). Proposed reserve areas at (i) were excluded from the final NPA due to plans for agricultural development related to commercial coffee plantations, whereas the area at (ii) was excluded due to state interests in timber values (Dwyer et al. 2015).

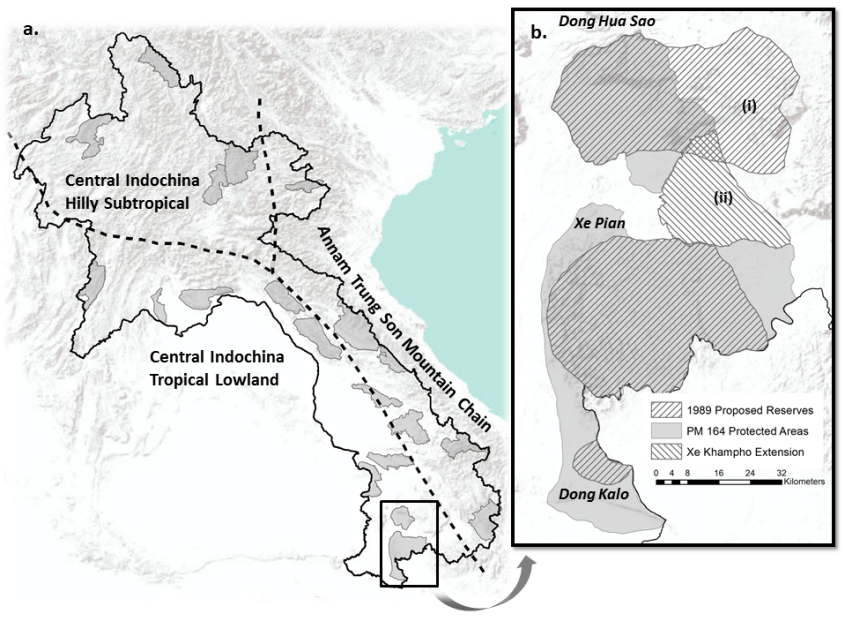

These assessments reflected particular sets of assumptions regarding nature and its relationship to local communities. The environmental narratives that proved formative in the creation of Xe Pian legitimized a fortress-like approach to conservation, defining "nature spaces" in very particular ways. This "fortress conservation" model of environmental governance (see Davis 2007) carried with it (at least) three important assumptions: (1) nature is something quite distinct from human society, (2) it is immediately threatened by the livelihood activities of local people, and (3) urgent intervention by state forest agencies and, in this case, foreign conservation nongovernmental organizations (NGOs) is the necessary fix. These measures were explicitly spatial, (re)defining and separating the spaces of nature from the spaces of local people (see also Baird 2009). Duckworth et al.
(1993) who carried out some of these surveys, recommended that human uses be controlled in the northern, more populated areas of Xe Pian, and be excluded entirely from the main block in the central portion of the reserve, and that all clearance of vegetation around wetlands be stopped entirely, regardless of location.

These surveys served as the technical basis for the establishment of the national forest reserve system by Prime Minister Decree 164 in 1993 (Government of the Lao People's Democratic Republic (GoL) 1993). Article 4 of the Decree included specific provision for the regulation of human uses inside the forest reserves, including prohibition of the holding of lands, the erection of houses, or the expansion of agricultural fields, allowance for the collection of nontraditional forest products (NTFPs) only by state permission, an absolute prohibition on "slash and burn agriculture" (or shifting cultivation, the primary livelihood strategy across much of Lao PDR's uplands) and the removal of any trees, with the exception of sampling for approved scientific purposes.

In the span of 5 years, these forests were thus redefined with reference to their conservation value in securing species of global significance against (primarily local) forest users and were incorporated into the national forest estate under the direct administration of government forest agencies. Whether a particular space was incorporated into the reserve system was the product of macroscalar processes - the 1986 global biogeographic mapping of MacKinnon and MacKinnon, the conservationist imaginings of foreign scientific advisors, and competing commercial interests of state authorities - all with material consequences for local social-ecological systems, explored below.

\section{MODERNIZING THE NPA, EXCEPTIONALISM, AND NEGOTIATION}

In the years that followed the 1993 Decree, modernization of the NPA became a focal concern of managers who sought to address the threats posed by local communities and other resource users. Situated firmly within a modernist conceptualization of nature - as something quite distinct from social systems and an object to be categorized, mapped, zoned, and conserved in particular ways and toward particular ends (Spaargaren and Mol 1992, Freudenburg 2005) - the modernization of environmental governance in Xe Pian was presented as something selfevident and uncontestable. Because regularizing and modernizing nature entails the simplification of social-ecological space and, especially, the differentiation of social space from ecological space (Escobar 1999), they produce displacement effects (Agrawal and Redford 2009) whether through displacement of peoples to outside protected areas or, perhaps more applicable here, in situ displacement where the spaces of local communities are redefined by conservation authorities, and access to certain resource uses are precluded. Under the guidance of foreign technical experts and an increasingly professionalized national forestry administration, conservation policies found material expression in a number of spatial processes in Xe Pian, beginning first with the demarcation of the NPA followed by village-level zonation and boundary making through the Land and Forest Allocation (LFA) program, culminating in the elaboration of the NPA management plan in early 2000 . 


\section{Demarcating the NPA}

The WWF's (1997) assessment indicated that clear and enforceable boundary demarcation would support not only conservation but also local interests and exclusionary place claims - a win-win. Although biodiversity assessments were carried out in the field, the boundaries of the NPA itself were imagined largely by resource managers at the central government level. One official involved in the designation of the NPA system reflected, "The NPA boundaries were just created on a map, no one really went to the ground level. Someone sat in an office and went [draws a circle in the air] with a marker." Although PM 164 had established Xe Pian and specified its area and boundaries on paper, the process of physically demarcating the NPA took several years and still remains a point of contention. In practice, the actual physical demarcation of the boundary proceeded irregularly and varied considerably with regard to the degree of local participation. The forestry official responsible for informing local communities of PM 164 reflected, "I remember the day Xe Pian was announced. We drove around to all the villages and informed them the forest was now a reserve. Some of the villagers, they were not happy about it. They were afraid the government was going to take their land. We argued with them and, in the end, they agreed. We just used the Road $18 \mathrm{~b}$ as the boundary since this was easiest" (interview, June 2015). An elder in a village along the northern extremity of the NPA recalled, "one day a truck came, and they just put the [boundary] stone down. They didn't even talk to us. They say now that the NPA boundary is right there, but this was all our land. Their land is way over there, more than a kilometer away" (April 2013). Although it was envisioned that place claims between forest managers and local communities could be shared but differentiated through overlapping sets of powers and responsibilities within areas traditionally under village management, the boundary of Xe Pian has come to be viewed as a symbolic as well as statutory differentiation of space and ownership. In one village whose traditional boundaries extend well into the NPA, a local elder was unequivocal, reflecting a perspective very common amongst participants across all villages: "This area belongs to the village but there, beyond their boundary, all belongs to government and not to us" (interview, June 2015, see referenced area at point (i) in Fig. $3 b$ ).

\section{The Land and Forest Allocation (LFA) program}

The demarcation of the NPA boundary was seen as a precondition to secure conservation outcomes, the presence of villages within and overlapping with Xe Pian required additional zonation and demarcation. The LFA program, enacted throughout the protected area toward the end of the 1990s was one of the key mechanisms employed to formalize these spatial differentiations at the local level, with the explicit goals of mitigating agricultural expansion and eradicating shifting cultivation. The LFA involved the identification and mapping of traditional village areas according to specified (and predefined) use zones, with such designations as "residential areas," "conservation forest," "use forests," "agricultural land," etc. (Fig. $3 b$ is exemplary). These maps then served as social documents recognizing (some) local customary place claims but also as regulatory instruments to sanction (and, by implication, censure) various local resource uses. In an effort to secure environmental values of interest to conservation managers, the LFA thus reduced the land available to local communities and (re)defined the meanings of particular spaces with normative (and legal) implications for local resource governance. Although this intervention was justified on the grounds that zonation and mapping of social-ecological systems was a necessary precondition for sustainable resource management and enhanced tenure security (Fujita and Phanvilay 2004), its application in practice suggests several adverse outcomes. Whatever its intention, the LFA has been widely criticized in Xe Pian with regard to its technical and procedural insufficiencies (GoL 2000), more generally for exacerbating resource scarcity and food insecurity, accelerating soil degradation by unsustainably intensifying agricultural activities (Lestrelin et al. 2005), undermining conservation objectives (Ducourtieux et al. 2005), and as a willful attempt to reterritorialize large tracts of land and place these under the control of the state, rendering them available for economic concessions (Vandergeest 2003, Barney 2009).

Fig. 3. $a$. Xe Pian NPA detail and $b$. LFA example from Ban (Village) Thahou. (a) Military control over strategic areas was established by PM111, later excluded from the REDD+ project along the with Xe Pian Main Block. (b) Village areas and landuse zones established by LFA. Village conservation forest areas overlapping with the NPA at (i) where village-level governance has been largely ceded to state forestry administration.

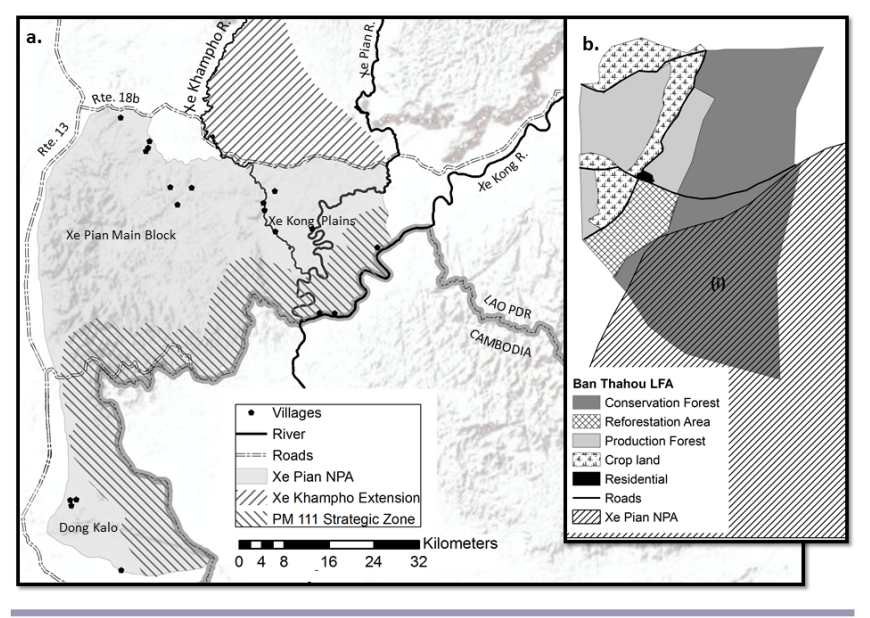

Alongside these direct outcomes, the LFA also introduced scalar mismatch between the management spaces of local communities and broader social-ecological system processes by delimiting and reducing the effective spaces of their operation (Cash et al. 2006, Cumming et al. 2006). Because of the legal ramifications of these categories, the particular spatializations produced through the LFA process in Laos have remained remarkably persistent through time, in many cases, showing very little change over the past two decades despite subsequent planning processes and changing market dynamics (Dwyer 2013). Thus, the LFA system functioned to harden system boundaries at a particular point in time according to predetermined use zones, limiting the ability of local communities to respond adaptively to changing system conditions, resource use, and conservation needs through time, potentially undermining system resilience (see Cumming 2011, Nelson et al. 2007). 


\section{The 2000 Xe Pian management plan}

In early 2002, the Global Environment Facility (GEF) supported the development of a management plan for the NPA (GoL 2000) that formalized the fortress conservation approach through a modernist conceptualization of nature. Under the management plan, mapping and zoning of Xe Pian became more detailed, with a continued emphasis on mitigating local threats to biodiversity values through regulation, patrolling, and law enforcement. Conservation planning continued to limit-although not eliminate - the scope for local management in favor of management through the state forest agencies. That local communities were not involved in the development of the management plan is indicative and was legitimized by conservation planners on the grounds that "the majority of communities living in and around Xe Pian NBCA do not have sufficient understanding... to participate meaningfully in preparing a management plan" (GoL 2000:5).

It was not only the putative ignorance of local communities and the destructiveness of their livelihood strategies, however, but also their sheer numbers that were of concern. The management plan identified population growth as a key risk and affirmed the right of the state to intervene to preserve conservation values, instituting a blanket proscription on the migration of households into the NPA. The WWF (1997:87) further recommended the promotion of contraception and birth spacing, concluding that "unless the human population in and around XP [Xe Pian] is curbed, trying to save or protect threatened animal species in XP may be futile."

Whereas proposed interventions in the management plan otherwise largely reflected previous prescriptions provided under PM 164 and the recommendations of technical advisors during Xe Pian's formulation (e.g., Duckworth et al. 1993, Timmins et al. 1993, WWF 1997), the management plan inaugurated a very important innovation: a turn toward an environmentalexceptional mode of governance (sensu McSweeney 1996), an explicit circumvention of normal legal processes in an effort to address pressing issues of biodiversity decline and environmental degradation. This exceptional mode of governance is perhaps most clearly manifest in the approach taken to two issues: (1) the degree of regulatory control of the protected area itself, and (2) provisions made for the territorial expansion of its management area. In the first case, the management plan specified that Xe Pian should be classified as an IUCN Category II National Park, allowing tourism, research, and spiritual and cultural values, but precluding even indigenous livelihood activities where these conflicted with superordinate conservation goals. The management plan further stipulated that until Xe Pian was legally designated as a Category II National Park, "it should be managed as if it had such a designation" (GoL 2000:61) with support from law enforcement agencies. In the second case, that of the inclusion of areas not specified in PM 164, we see a similar approach. Although the management plan interpreted PM 164 to require Prime Ministerial approval for the retraction of NPA boundaries, it nevertheless allowed for their expansion - thus the enclosure of more space under a particular mode of environmental governance - at the discretion of forestry authorities who would manage these incorporated spaces "as if they were part of the NPA until such a time as was legally recognized" (GoL 2000:20). The most ambitious attempt at this extrajudiciary enclosure involved the proposal to include the so-called Xe Khampho Extension area, connecting Xe Pian to Dong Hua Sao NPA in the north (Fig. 3a). During the early stages of the forest reserve system, this area was of particular interest to conservation advocates as a connectivity corridor between the two NPAs. Although this area was not included under PM 164 due to the interests of provincial authorities in its high-value timber (Dwyer et al. 2015), it was nevertheless incorporated into the administrative space of the NPA management plan with the provision that it should be regulated until such a time as its standing could be legally established. In the end, the Xe Khampho area was incorporated as a state-managed Biodiversity Corridor with support from the Asian Development Bank. The implications of these legalexceptional proposals are significant. Although ostensibly promoting the rule of law and a state-centric narrative of biodiversity conservation, these provisions legitimized special, extra-legal measures to secure biodiversity values through the discretionary enclosure of lands by forestry agencies in a manner that circumvented normal legal processes and associated social and procedural safeguards.

In the years that followed NPA, authorities had to deal with the practical reality of implementing NPA management policies against antecedent territorial claims of local communities. Among government officials participating in this research, there was a marked ambivalence about the rights of communities within these forested areas. One forestry official (interview, June 2015) reminded me "it is not like in your country. We already had people living in these forests, we could not just move them out. In the beginning, we considered it, but it would be very expensive and we couldn't afford to move them." A senior official at the Ministry of Natural Resources and Environment (MONRE), whose mandate includes NPA management, reflected similarly on the difficulty of spatially differentiating these place claims (October 2014) "we need to decide the limits of the areas of the villages inside the NPAs. Where does the village area end and the government's area begin? Where are they forbidden to clear, or do they need to be resettled outside the NPA altogether?" Such questions of state vs. village control of space remain a key point of contention in contemporary reforms of land administration. In 2014, the National Assembly requested management agencies to revise and redelineate land and forest areas under the state administration (National Assembly 2014). One senior land administration official responsible for this redelineation was trenchant, "This process must begin first at the national level, we cannot ask the villagers. For sure, the villages will want to take whatever land they can get. We need to define first what belongs to us, and then after that ask them" (interview 2017). Implementation of spatial enclosure and categorization on the ground suggested a degree of give-and-take. An elder in one village inside Xe Pian (June 2015) recalled, "When they first came to announce the establishment of Xe Pian, we really argued with them. We said 'we have been more than 100 years, we have lands here, we have rice paddies! How will we live?' It was like the fon la vong [a traditional Lao dance], we went round and round with them. In the end, they said we could keep the fields we already had, but we could not open new fields." The management plan formalized these spatial negotiations, allowing resident communities the right to a "basic standard of living" but with the proviso that "individuals and families who aspire to more than 
this will be encouraged to leave the protected area and seek opportunities to realize their ambitions elsewhere" (GoL 2000:11). Poulsen and Luanglath (2005) record at least one incident where this regulation had to be enforced in a case where a young household had created new agricultural land and were subsequently disciplined and forced to find land outside of the NPA. Perhaps a more surprising outcome of these negotiations was that conservation advocates were not in the end able to sustain the level of control envisioned for the reserve, which was downgraded to IUCN Category VI Protected Areas with Sustainable Use of Natural Resources.

Policies and conservation measures to mitigate the risk that local communities might expand their agricultural areas due to population growth or a desire to increase their standard of living intersected problematically with social development goals. Although local communities were allowed to retain approved, pre-existing land holdings, specific provision was made to disallow the issuance of land titles to communities within the NPA, or the use of their lands as collateral for securing development loans (GoL 1993, Article 4). An official at the Ministry of Natural Resources and Environment (February 2015) reflected on this difficulty, not only because more secure ownership in the form of land titles might compete with conservation goals, but also that it might conflict with state interests: "we have to consider the livelihood needs of communities, but also to consider when and how to take away the land when it is appropriate, and transfer it to state uses, and the best way to go about this. After all, of course, all land belongs to the state."

Although boundary demarcation, zoning, and other spatial classifications form an often unquestioned technology in the management of environmental resources (Zimmerer 2003), these spatializations are more than technical processes; they reflect and reproduce power relationships within social-ecological spaces by embodying particular environmental narratives (Walker and Peters 2001). The various spatial processes in Xe Pian differentiated "state" vs. "local" space claims, redefined the meanings of these spaces and established legal norms for what kinds of uses-and thus what kinds of social-ecological outcomes - were (dis)allowed in each. These spatializations were, however, socially differentiated both in the processes through which they were produced as well as in the subsequent meanings of those spaces and of the boundaries that enclose them. This dynamic of differential access, ownership, and meaning - and the ecological implications of these variations - are most clearly exemplified in the related issues of security, timber extraction, and trade in the NPA, subjects that will occupy much of the rest of the paper.

\section{MILITARIZATION, ROSEWOOD, AND THE BORDER}

The spatialization of power within these remote areas on the periphery of the state adjacent to international borders took on a special character as they encountered discourses of state security. Xe Pian's social and ecological conditions-remote, forested, and proximate to the Cambodian border-played an important role in producing a space attractive not only to conservationists but also to politico-military dissidents during two historic periods.
Conflict legacies and the militarization of the timber trade

During the protracted conflicts of the 1960s and 1970s, several thousand Lao and Vietnamese Communist insurgents took refuge in Xe Pian, distant from both Royalist and colonial military forces and protected by the forest canopy from aerial observation. A local villager and former insurgent, now living on the outskirts of the NPA recalled, "During the war, we lived for a long time in the forest. The regular people could stay in the village but we, the young men who fought for liberation, could not stay. We had to live in the forest, maybe $10 \mathrm{~km}$ away [he points south]" (interview 2015). Villages further inside the NPA played a pivotal role in hosting these insurgents. An elder in one village was proud, "we were a revolutionary village. Fighters came from two provinces to stay in our village" (interview 2014). More than a decade later after Laos had achieved its independence, Xe Pian again became the refuge of political refugees and military insurgents, as the Khmer Rouge lost power in Cambodia and dissident fighters fled across the border. These periods of insecurity loom large in social memory. "Many years ago," according to one village elder (interview, June 2015), "the black-shirts [Khmer Rouge] came into the forest, but mostly over toward the east and south. We were afraid to go into the forest." One conservation practitioner who grew up in Xe Pian recalls his childhood during those years, "when I was young, sometimes they would come to village and tell us 'there are terrorists in the forest near the village' and then we would not go. I think the adults also were afraid, they were afraid that if someone saw them going into the forest, the government would think they were collaborators with the black-shirts" (interview, February 2015).

Insecurities related to the intrusion of Khmer Rouge fighters and more general concerns relating to national sovereignty and the control of the international border have resulted in a large military presence in Xe Pian. Although the primary strategic focus of the military has been on the areas immediately adjacent to the international border, the spaces controlled by state security forces have been highly fluid in space and time in response to insurgency events and, perhaps as often, opportunities for the extraction of timber. The 1992-1993 biodiversity surveys, for example, although persistently excluded from military controlled areas in the Xe Kong Plains (Timmins et al. 1993), were also interrupted by ad hoc military exclusions and the eviction of survey teams on reports of "terrorists" in the Dong Kalo area. Temporary and area-specific exclusions, however, were also used to restrict access by both foreign advisors and state forest managers in cases ostensibly unrelated to security, such as during road construction (WWF 2013) and logging by the military (Claridge 2000).

Although the militarization of space in Xe Pian interrupted scientific surveys and the access of regulators - in this sense apparently at odds with the goals of modernizing environmental governance in the NPA - it also came to serve the practical interests of conservation advocates where it produced enhanced regulatory control and disarming of the local population. For example, under the conviction that subsistence hunting and poaching of marketable species were key local drivers of biodiversity decline, the management plan instituted a ban on all firearms in the NPA, "except for by government officials in performance of their duties" (GoL 2000:49), with the police carrying out operations to confiscate guns throughout villages in the NPA on at least two occasions during the following 4 years 
(Poulsen and Luanglath 2005). Disarming the local population in the interests of securing biodiversity values - all legitimized by particular narratives of insecurity that framed local communities, and not military agencies, as threats - was synchronous with the expansion of state security forces, which began to play a more active role in patrolling and law enforcement within the NPA.

From the very beginning, conservation controls applied very differently to different sets of actors in Xe Pian. Although local threats to forest loss were largely controlled, commercial logging by other actors continued apace regardless of its illegality under Article 4 of PM 164. Biodiversity and habitat surveys by Timmins et al. (1993), Duckworth et al. (1993), and Bezuijen et al. (2007) all noted log landings and skid trails concentrated within the south-central and southern portions of the NPA and along the Cambodian border, such as at the security checkpoint at the confluence of the Xe Pian and Xe Khampho rivers. Although these did not generally attract official comment, a concession of $5,000 \mathrm{~m}^{3}$ of timber from the northern portions of the NPA inside in 1999 prompted formal enquiry by project donors. Although the concession was granted to a state-private joint-venture company for the clearance of wind-fallen timber, a World Bank investigator reported that timber was taken from an area of approximately $8-9 \mathrm{~km}^{2}$ within the NPA, with $83.5 \%$ of timber being taken from standing trees (Claridge 2000). These logging events, although substantial and apparently in direct conflict with the provisions of PM 164 and the conservation objectives that formed the basis of restricting local access to resources in Xe Pian, were only a foreshadow of what was to come. The pace and scale of logging operations and the dispute surrounding these operations came to a head around 2010 as the global market for rare tropical rosewoods, especially Dalbergia cochinchinensis, exploded. Chinese demand for this rosewood-valued upwards of US $\$ 50,000$ per $\mathrm{m}^{3}$ - incentivized an unprecedented expansion of trade networks across Southeast Asia (Environmental Investigations Agency (EIA) 2014) but especially within forested areas along international borders such as Xe Pian, where the remaining stocks of rosewood could still be harvested (Singh 2013). According to local communities, this led to the issuance of logging permits to at least two companies in Xe Pian by 2012, which, in the one case informed villagers that they had been authorized to cut timber for the construction of houses for senior government officials and, in the case of the other, to recover rosewood that had been illegally logged by Cambodians (village elders, May 2013). The military was similarly active, invoking state security privilege to prompt the issuance of Prime Ministerial Decree 111 (see GoL 2011) conferring control of forested border areas to the military and a specific derivative concession to the provincial military units to clear border areas within Xe Pian for the purpose of establishing a road connecting Route 13 to the confluence of the Xe Pian and Xe Khampho Rivers. These provisions-albeit legal exceptions by executive decreeprovided a veneer of legitimacy to a much more ambitious program of military expansion throughout Xe Pian. By 2013, military logging encampments were reported in several areas throughout Xe Pian far distant from those areas authorized under PM 111 (interviews, April 2013).

\section{Local agency, artisanal logging, and conflict}

These efforts to enclose and control the social-ecological spaces of $\mathrm{Xe}$ Pian, however aggressive or legitimized, were not hegemonic. It was not only state-sanctioned companies and the military that mobilized to take advantage of the lucrative rosewood market. Local villagers became increasingly involved, sometimes as guides for companies, but often on their own initiative. One elder in a northern village explained, "We protected this forest for years. When they announced the opening of the protected area, they told us it was our national duty to protect the forest. Now, they are all cutting - the big people, the military -if they are going to cut, why shouldn't we cut, too?" (interview, February 2012). For some villagers, logging of timber in the protected areas was a practical necessity in the face of endemic poverty and economic insecurity. One woman explained, "The rice is never enough, we plant each year but the snails eat it all. There is nothing left for us to do but cut trees" (interviews, June 2015). Although in some cases, villagers were themselves involved in illegal logging in Xe Pian and thus were not passive participants in these globalized networks of trade, they participated on a highly uneven field. Villager participation in the logging of rosewood and other species, even for approved purposes, led to a spate of arrests between 2012 and 2013 and heightened tension between local communities and the military. A village leader recalled one particular incident in March 2013, "We had gone to the forest to collect timber for the construction of a house for a newly married couple. When the military came, I fled deep into the forest. The others, though, they were caught." In this case, seven local community members were imprisoned by the military, and their equipment, hand-tractors, and timber confiscated. A development practitioner working in the province lamented, "the villagers [involved in timber harvesting] are really struggling. They have to work in these dangerous conditions and fear getting caught between the forest and the sawmill. But the people at the top - the very people they are afraid of - they are the ones really doing well from this, making a lot of money" (interview, June 2015). Although these conflicts centered on high-value rosewood, the spatial distribution of these timber species within village areas has had implications for the control of space more generally, destabilizing local resource governance. One village elder explained, "In the past, if people from other villages wanted to come and collect things from the forest, they would come to us and ask permission. Now the military has taken over. They told us 'this forest belongs to the army now.' Now people from other villages don't even ask us anymore, they just talk to the army" (interview March 2013).

Disputes over space and resources played out not only between local communities and the military, but also between government agencies within the NPA. The expansion of military power throughout the NPA led directly to the retraction of the administrative space of state forestry agencies. Driving past a checkpoint in the NPA in March 2013, a forestry official commented "these are supposed to be staffed by forestry staff as well as police and military, but now they have all been taken over by military personnel. We cannot even carry out [law enforcement] patrols anymore, the military will not allow us."

Tensions surrounding Xe Pian's southern border with Cambodia, and the flow of timber resources across this border, have become increasingly international and militarized in recent years. In April 2016, the Royal Cambodian Army blockaded the movement of supplies for the construction of a Lao military outpost along a timber trade route, reputed to be within disputed border territory 
(Radio Free Asia 2016). Tensions simmered until February 2017, when 400 troops of the Lao People's Army crossed into Cambodia to halt the construction of a road across the border from Xe Pian NPA. The armed standoff continued until late February, prompting an urgent meeting between Lao President Bounhang Vorachit and Cambodia's Prime Minister Hun Sen on 22 February in Phnom Penh (Khmer Times 2017).

These disputes over space-and the governance of spatially situated ecological resources - have all been conditioned not only by the geographic expansion of the military, but also by the discourses through which these actions have been legitimated within Xe Pian. Dwyer et al. (2015) traced the ways in which narratives of historical border insecurity have become intertwined with contemporary notions of economic insecurity relating to the leakage of valuable timber, justifying security exceptional modes of governance along Laos's border areas. In Xe Pian, these discourses have also intersected with antecedent discourses of environmental (in)security, materializing in a fluid, changing geography as the social-ecological spaces of local communities were further diminished by the aggressive extension of military control. This reterritorialization has undermined local community control and access to spatially distributed resources, as well as the administrative spaces of state forestry agencies, furthering ecological degradation and deforestation through extensive logging. By 2014, 212 ha of the NPA were deforested for the development of a military access road along the Cambodian border (Hansen et al. 2013) that provided access for extensive selective logging throughout the NPA. In June 2017, the Deputy Prime Minister visited the Champasak Province to pressure local authorities to address the increasingly visible timber trade problem. Provincial authorities responded quickly, confiscating illegal timber, officially reporting at least $54,000 \mathrm{~m}^{3}$ of logs stockpiled outside the NPA (Vientiane Times, 12 June 2017).

Analysis of complex systems suggests that large-scale disturbance events (catastrophic storms, flooding events, forest fires, etc.), create lasting legacies with path-dependent social-ecological outcomes through space and time (Adger 2000, Folke 2006, Davidson 2010, Cumming 2011). We see here a particular sort of disturbance legacy, relating to the sociopolitical upheaval concomitant with war and its aftermath. Although the prolonged presence of military (both during the Lao independence movement and subsequent to the fall of the Khmer Rouge across Xe Pian's southern border) undoubtedly had immediate socialecological impacts, a lasting artifact of these disturbances was the construction of narratives of insecurity that provided the justification for militarization in Xe Pian and the enclosure of border areas under the administration of state security agencies, all of which created an enabling environment for large-scale logging and the trafficking of high-value rosewood.

\section{THE NEOLIBERAL MARKET AND THE COMMODIFICATION OF XE PIAN NPA}

These sorts of disputes over resource governance and access are, of course, not unique to Xe Pian. The failure of traditional "fortress conservation" models and growing unease with the ineffectiveness of environmental administration by the state have given rise to new sorts of discourses, propped up by a different set of assumptions. Emphasizing the contribution of the environment to the global socioeconomy through various ecosystem services, and noting that specific monetary values can be attached to these services, new forms of governance emphasize the win-win of environmental conservation - that biodiversity and other values can be conserved whilst also ensuring economic growth if the market is brought to bear upon the historically intractable problems of environmental governance. The neoliberal market - particularly a market propped up by the state but liberated from its control-may be the savior of nature and not its rival (Oels 2005).

In the face of intractable drivers of global forest loss and climate change, neoliberal environmental governance has found material expression in REDD+, a market-oriented mechanism for securing standing forest carbon stocks. Since its beginning, the active management of Xe Pian depended almost entirely on funding from foreign conservation NGOs and donors, pointing again to the role of these actors in operationalizing power in the NPA (Arts and Buizer 2009). The possibility of sustainably financing conservation through the commodification of forest carbon prompted the WWF to initiate the Xe Pian REDD+ project in 2013, beginning a new phase in the management of the protected area. In a sense, the NPA provided an ideal space for the implementation of REDD+, not only because of its substantial carbon reserves but also because the now-weakened ownership claims of local communities promised simpler regulatory control and reduced project transactions costs. One technical advisor explained (August 2014), "In the beginning, we considered other options, but we realized that the tenure arrangements outside of the NPA were too complicated, we would have to sign separate agreements with many different land owners. In the NPA, things were easier to control, transaction costs lower because the land was all under the government. Also, there were stronger regulations for land use inside the NPA already, which we didn't have outside." The retraction of community control over forest areas and the simplification of governance arrangements under the state thus served to benefit the emergence of REDD+ in the NPA. These simplifications, however necessary to facilitate REDD+, were not sufficient. The project had to grapple with the issue of economic land concessions for rubber plantations (which, in at least two cases, had displaced local land uses onto Xe Pian (WWF 2013)) as well as the rather more intractable problem of (officially and unofficially) approved military logging and forest clearance - both key drivers of forest change in Xe Pian. Because these drivers of forest change were authorized by state actors, they were determined to constitute planned drivers of deforestation and were thus ineligible for inclusion under REDD+ which, at the project level, was designed to address unplanned deforestation only. The spaces impacted by these - nearly $41 \%$ of the NPA (Fig. $3 a$ ) - were thus excised from the project area (WWF 2013). With these areas removed from the project space, identification of the drivers of deforestation and forest degradation was simpler and, almost predictably, came once more to focus attention on local communities. The technical lead on the project concluded that "[Deforestation and forest degradation] is mainly caused by the local population living in and around the NPA who need timber for house construction and fuel wood" (interview, November 2011). Proposed interventions to mitigate these local drivers were not surprising: boundary demarcation, improved zoning, mapping, improved law enforcement and patrolling, and greater 
involvement of military and police with patrols (WWF 2013:20). That these interventions would entail livelihood impacts in an area with a high incidence of poverty was taken into consideration by project developers, who recommended compensation for local communities through off-farm employment and agricultural intensification. Although the project was approved by the Verified Carbon Standard in 2015 without an agreed upon benefit-sharing mechanism to distribute carbon revenues, it was uncritically assumed that financing for livelihood compensation would be provided by the state forest agencies to whom these revenues would accrue.

In some sense, the REDD+ project represents something new in Xe Pian, drawing on new discourses and incentive structures. By commodifying carbon in existing forest stocks, REDD+ attributes new value to standing trees as an alternative to timber harvesting or the conversion of forest for cash crops. Still in its early stages, it remains to be seen whether REDD+ will be able to deliver on both its environmental and social promises in $\mathrm{Xe}$ Pian. We may anticipate a little, however, noting there are reasons for concern. REDD+ articulates market-based solutions to issues of forest governance in ways that may reinforce, rather than challenge, the existing status quo (Okereke 2006, Ingalls and Dwyer 2016). In the case of Xe Pian, this is manifest in the way that REDD+ assiduously avoided the thorny issues of plantation concessions and the problematic and legal-exceptional operations of the military by extracting these geographies from its project space, thus truncating the possibility of engaging with structural drivers of forest change in Xe Pian (see Dwyer and Ingalls 2015 for a more detailed analysis). Furthermore, limiting its spaces of engagement to those impacted by local livelihood practices, REDD+ not only valorized a narrative that positioned local communities (rather than commercial logging companies or the military) as agents of degradation, it also reproduced historical and socially problematic approaches to redefining the socialecological spaces of local communities. Through the creation of new market values and by directing the revenue derived from these values toward state agencies, REDD+ may function to further centralize forest governance (Phelps et al. 2010) and produce new conflicts between local forest users and forestry officials where carbon and noncarbon values compete (Wilson and Howarth 2002).

The creation of any new value intersects with existing values and disputes and may variously reproduce or change them (Fabinyi et al. 2014). The enabling conditions within Xe Pian that facilitated REDD+, such as large carbon stocks, heightened regulatory control, and limited local ownership claims were the legacy of PM164 and subsequent measures to maintain forest stocks by delimiting the territorial claims of local communities and promoting greater government control. Whatever its explicit and implicit assumptions and promises, REDD+ was thus not introduced into a blank and undifferentiated space. Rather, it mapped out problematically across a sociopolitical space that had been shaped by antecedent resource claims, regulatory controls, and spatialized power networks (see also Buizer et al. 2014). In this sense, REDD+ is less new than it was presented to be. The proposed activities of REDD+, the distribution of its costs and benefits, all reflect and reproduce pre-existing power asymmetries among local resource users, state agencies, and international conservation organizations. As with previous interventions in $\mathrm{Xe}$
Pian, REDD+ links these local social-ecological systems to global networks of power, this time through the neoliberal carbon market. How these new networks of power impinge upon these systems, and with what implications for social-ecological processes and outcomes, will play an important role in the resilience of these systems far into the future.

\section{THE SPATIALIZATION OF POWER IN SOCIAL- ECOLOGICAL SYSTEMS: SOME FURTHER OBSERVATIONS}

I have sought to demonstrate that analysis of complex systems necessarily entails the unbundling of the social-ecological relationships in space and through time and the interrogation of the power asymmetries that constitute and politicize ostensibly technical and managerial interventions in the governance of social-ecological systems. Dispute involves not only a range of actors but also an equally broad range of attributed values. $\mathrm{Xe}$ Pian as, variously, a livelihood resource, a habitat for species of global significance, a source of commercially valuable timber, or a store of carbon as a solution to global climate change, forms the objects of these disputes that overlap in space and time. There are four general observations that emerge from this.

First, power relationships become written onto the spaces of social-ecological systems through patterns of access, inclusion, exclusion, and control across space and through time, with important implications for the analysis and management of social-ecological systems. In Xe Pian NPA, these spatializations found material expression through the interaction of global ecoregional assessments and national forest planning, drilling down to increasingly local levels through processes of demarcating the boundaries of Xe Pian, management zonation throughout the NPA, and village-specific LFA processes. These spatializations constituted a clear reorganization of space and the attributed meanings of those spaces, uses, and management outcomes, (re)producing asymmetric relationships of power. Although the social processes that produced new spatial arrangements in Xe Pian NPA were framed as mere technical interventions necessary to secure environmental values - the legitimacy of which was selfevident and presumably uncontestable (Escobar 1999) - their implications were clearly more than technical in nature. Boundaries (and other forms of spatialization), we are reminded, are not objects so much as expressions of social relationships, carrying socially differentiated meanings that vary by actor (Ribot and Peluso 2003), allowing some forms of access to some resources for certain people while excluding other people and/or other uses. Whether some spatial object (whether field, fallow, or forest) was mapped into the protected area or not, zoned for conservation or use, or categorized for some specific purpose necessarily entails particular social and ecological outcomes. Insofar as these intersected with contested social values and produced differential social-ecological outcomes, they are moral and political acts and should be analyzed as such (Cote and Nightingale 2012, Ingalls and Stedman 2016). This impinges on (at least) two core precepts in resilience: (1) selforganization and decentralization in management and (2) hardening of system boundaries. The resilience of a particular social-ecological system depends in large part on the ability of that system to selforganize, a condition enabled by decentralization in management (Chaffin et al. 2016, Walker et al. 2004). As spatial processes within Xe Pian 
increasingly refined and demarcated various areas, state forest agencies assumed control of larger and larger forested areas, mitigating and limiting the direct control of local communities, such as over nontimber and other forest products as highlighted above where these resources came under the control of forestry and state security agencies. Those areas in which local communities retained direct control were yet further restrained by zonation performed under the LFA, which specified what sorts of uses were (il)licit. As we have seen, however, even the limited control domain of local communities has in some cases been erased, perhaps temporarily, by the expansion of military control. The externally driven rearrangement of space creates scalar mismatches between the spatial dimensions of key system processes and the spatial management domains of local institutions, undermining adaptive management (Cash et al. 2006, Cumming et al. 2006). That these multilevel spatial categories and associated land uses and regulatory controls were inflexible through time points to implications for the second of these core principles of resilience: the ability of systems to change and adapt and change over time in response to changing system conditions. Insofar as change (vs. stasis) is the norm within complex systems, the hardening and formalization of boundaries without clear processes for modification critically undermines adaptive capacity (Nelson et al. 2007, Yarrow and Marín 2007). This is particularly problematic where local participation in the designation of these zones was limited at the outset (Zimmerer 2003).

Second, although each of these interventions (e.g., formation of the NPA, securitization, and REDD+) were in some sense new, they were shaped by antecedent social-ecological conditions. These included biophysical characteristics - especially large tracts of forest, sparse population density, and remotenessallowing for and prompting conservation interests as well as creating conditions attractive to politico-military dissidents whose presence in these forests in turn gave rise to questions of (in)security and militarization. The distribution of high-value rosewood species along the border further complicated these spatial relationships and provided the impetus for particular expressions of power related to regional timber markets and the role of the military as a market actor. This all suggests that the spatialization of policies and interventions do not map onto blank social-ecological spaces. Whatever the explicit goals of management interventions, these are shaped in practice by antecedent system conditions in ways that confound linear causal pathways between policies and programs and their socialecological outcomes, while also functioning to reproduce historic power asymmetries. Conceptualizing this within the panarchy cycle (an oft-referenced conceptual object in resilience thinking), these system preconditions may be seen to constitute large, slow variables that frame and shape local, faster processes (see Gunderson 2001, Cumming 2011). Although some of these are material in nature (e.g., distribution of high-value timber resources and attributes of forest density), others are political and discursive. Historic military insecurity fostered the construction of narratives of insecurity that legitimized the expansion of military control through these areas, constituting a form of postdisturbance legacy.

Third, although the dynamic interplay of power materializes in very local spaces, social actors draw on extralocal discourses to lend power to disputed narratives and legitimize and bolster competing claims. These disputes are bound up in (not only) socially constructed environmental narratives that (de)legitimize the claims of actors who compete across a very uneven terrain. These legitimizing discourses - invoking (for example) conservationist necessity, national security, or the urgency of climate mitigation - draw on other, cross-scale networks of power involving international conservation organizations, forestry and state security agencies, and global carbon markets. Common-pool resources are increasingly cast as global resources, and thus in an increasingly globalized world, local actors are perhaps more marginalized in cross-scale interactions and power negotiations because they are far outweighed (Adger et al. 2006). These global environmental claims found their earliest expression in the formation of Xe Pian through the application of MacKinnon and MacKinnon's (1986) biogeographic zonations, which were disaggregated by conservationists to map out Laos's NPA system. New environmental claims relating to mandates for the protection of species of global significance and, later, carbon sequestration and avoided deforestation intersected with questions of state security and regional timber markets to further marginalize local actors (Dwyer et al. 2015). It is suggestive, I think, to observe that the invocation of these higher-order claims in the ordering of local spaces suggests a new application for one of spatial resilience's core concepts of spatial subsidies (see, e.g., Carpenter et al. 2001, Cumming 2011, Allen et al. 2016): subsidies may be discursive as well as material.

Finally, although the landscape of dispute and negotiation is highly uneven, we are reminded that power is never hegemonic in its expression, being variously reproduced or attenuated both by lateral competing power claims (such as between state security forces and forestry officials) as well as by vertical dispute of power by local actors. Communities exhibited active agency through opposition to boundary claims, negotiation of livelihood spaces, and through their active participation in illegal logging in the NPA. This suggests that although policy may undermine local management, there are finer channels through which communities exert a measure of control over social-ecological space. This instills some hope for agency and local resilience while also reminding us that the expression of this agency may also be problematic, such as in the participation of local communities in the trafficking of endangered rosewood. Although formal institutional processes within Xe Pian have allowed for some degree of local participation, it is significant to note that expressions of agency illustrated above were largely outside of these formal processes and, in some cases at least, illegal. Social resilience is in large part an emergent property of local agency (Pain and Levine 2012, Westley et al. 2013) and the degree to which larger social structures foster local participation in management and the distribution of resources and risks between scales (Adger et al. 2006). The degree of procedural and distributive justice in these negotiations plays a central role in the building of social capital between local managers and larger social institutions, another key element in resilience and adaptive governance (Adger 2001, Lebel et al. 2006, Nelson et al. 2007). Although resilience may be best fostered through participatory and navigational management processes (Ross and Berkes 2013), the formal management of Xe Pian has, in the main, been prescriptive in nature and characterized by limited local participation. 


\section{CONCLUSION}

These observations have, I think, important implications for the practice of research and management. In the first place, they reinforce calls to attend to both social and ecological dimensions of complex systems. Although management interventions to secure important conservation values in Xe Pian may foster resilience along environmental dimensions, a lack of attention to social elements and processes-and, in particular, how asymmetrical power relationships operate within these - appears to run at cross purposes, undermining other critical elements of resilience. This suggests that more attention should be paid to the implicit operations of power within complex systems that may operate below the radar of institutional analyses. Complex systems research should focus not only on formal management arrangements, but also on the subtext of how these have come about, the assumptions that support them, and their implications for real-world outcomes. This may not only nuance and problematize analysis of complex systems, but may produce entirely different insights and indicate quite different directions for research and management. Second, this suggests that not only managers, but also scholars and researchers are themselves bound up in these power dynamics. The discourses that (de)legitimize various approaches to ordering social-ecological relationships across space-time enjoy varying degrees of purchase among analysts and construct the taken-for-granted frames of reference that inform research practice. To whatever degree researchers variously draw on, support, or undermine competing social and environmental narratives, they become active agents in these disputes, highlighting the moral and ethical implications of resilience scholarship. A resilience framework sensitized to the operations of power across the spatial and temporal domains of complex systems may not only demonstrate enhanced analytic capacity but also greater liberating potential for subaltern actors in society.

This all suggests a fruitful line of enquiry. More work needs to be done in untangling the spatialities of power within socialecological systems across a range of settings including, for example, how power manifests during armed conflict and periods of political and institutional transition, or how these processes intersect with global environmental change.

\section{Responses to this article can be read online at: http://www.ecologyandsociety.org/issues/responses. $\mathrm{php} / 9543$}

\footnotetext{
Acknowledgments:

I would like to thank the many individuals and organizations in Lao PDR and elsewhere who have supported or participated in the process that has led to this paper. In particular, I would like to thank the World Wide Fund for Nature (WWF) Greater Mekong and the International Union for the Conservation of Nature (IUCN), who hosted much of this research. This paper has benefited from the constructive feedback of Rich Stedman, Jim Lassoie, Chris Barrett, and Steven Wolf, all at Cornell University. I would also like to thank two anonymous reviewers, whose suggestions have contributed
}

significantly to this work. This research was funded in part by the U.S. National Science Foundation.

\section{LITERATURE CITED}

Adger, W. N. 2000. Social and ecological resilience: are they related? Progress in Human Geography 24(3):347-364. http://dx. doi.org/https://doi.org/10.1191/030913200701540465

Adger, W. N. 2001. Scales of governance and environmental justice for adaptation and mitigation of climate change. Journal of International Development 13.7:921-931. http://dx.doi. org/10.1002/jid.833

Adger, W. N., K. Brown, and E. L. Tompkins. 2006. The political economy of cross-scale networks in resource co-management. Ecology and Society 10(2): 9.

Agrawal, A., and K. Redford. 2009. Conservation and displacement: an overview. Conservation and Society 7(1): 1. http://dx.doi.org/10.4103/0972-4923.54790

Allen, C. R., D. G. Angeler, G. S. Cumming, C. Folke, D. Twidwell, and D. R. Uden. 2016. Quantifying spatial resilience. Journal of Applied Ecology 53(3):625-635.

Arts, B., and M. Buizer. 2009. Forests, discourses, institutions: a discursive-institutional analysis of global forest governance. Forest Policy and Economics 11(5):340-347. http://dx.doi. org/10.1016/j.forpol.2008.10.004

Baird, I. 1997. A preliminary assessment of the aquatic resources of Xe Piane National Biodiversity Conservation Area, southern Lao PDR. World Wide Fund for Nature (WWF) Thailand Project Office, Bangkok, Thailand.

Baird, I. G. 2009. Spatial (re)organization and places of the Brao in southern Laos and northeastern Cambodia. Singapore Journal of Tropical Geography 30:298-311.

Barney, K. 2009. Laos and the making of the "relational' resource frontier. The Geographical Journal 175(2):146-159. http://dx.doi. org/10.1111/j.1475-4959.2009.00323.x

Barrett, C. B., and M. A. Constas. 2014. Toward a theory of resilience for international development applications. Proceedings of the National Academy of Sciences 111(40):14625-14630. http:// dx.doi.org/https://doi.org/10.1073/pnas.1320880111

Berkmüller, K., T. Evans, R. Timmins, and V. Vongphet. 1995. Recent advances in nature conservation in the Lao PDR. Oryx 29(4):253-260. http://dx.doi.org/10.1017/S0030605300021244

Bezuijen, M. R., R. Akchousanh, and C. D. Hallam. 2005. Observations of wetland resources use in Xe Pian National Protected Area, Lao PDR. Wildlife Conservation Society, Vientiane, Lao PDR.

Bezuijen, M. R., C. Phothitay, S. Chanrya, A. Rasphone, and C. D. Hallam. 2007. Wetland resource use in Xe Pian National Protected Area, Lao PDR, in 2005. Natural History Bulletin of the Siam Society 55(2):223-234.

Bolliger, J., H. Lischke, and D. G. Green. 2005. Simulating the spatial and temporal dynamics of landscapes using generic and complex models. Ecological Complexity 2(2):107-116. http://dx. doi.org/10.1016/j.ecocom.2004.11.005 
Buizer, M., D. Humphreys, and W. de Jong. 2014. Climate change and deforestation: the evolution of an intersecting policy domain. Environmental Science and Policy 35:1-11. http://dx.doi. org/10.1016/j.envsci.2013.06.001

Carpenter, S. R., and W. A. Brock. 2004. Spatial complexity, resilience, and policy diversity: fishing on lake-rich landscapes. Ecology and Society 9(1): 8.

Carpenter, S., B. Walker, J. M. Anderies and N. Abel. 2001. From metaphor to measurement: resilience of what to what? Ecosystems 4(8):765-781. http://dx.doi.org/https://doi.org/10.1007/s10021-001-0045-9

Cash, D. W., W. N. Adger, F. Berkes, P. Garden, L. Lebel, P. Olsson, L. Pritchard, and O. Young. 2006. Scale and cross-scale dynamics: governance and information in a multilevel world. Ecology and Society 11(2): 8.

Chaffin, B. C., H. Gosnell, and B. A. Cosens. 2016. A decade of adaptive governance scholarship: synthesis and future directions. Ecology and Society 19(3): 56. http://dx.doi.org/10.5751/ ES-06824-190356

Claridge, G. 2000. Logging in Xe Pian National Biodiversity Conservation Area: ramifications for management planning. Forest Management and Conservation Program (FOMACOP) Project, Vientiane, Lao PDR.

Cote, M., and A. J. Nightingale. 2012. Resilience thinking meets social theory situating social change in socio-ecological systems (SES) research. Progress in Human Geography 36(4):475-489. http://dx.doi.org/https://doi.org/10.1177/0309132511425708

Cumming, G. S. 2011. Spatial resilience: integrating landscape ecology, resilience and sustainability. Landscape Ecology 26:899909. http://dx.doi.org/10.1007/s10980-011-9623-1

Cumming, G. S., D. H. Cumming, and C. L. Redman. 2006. Scale mismatches in social-ecological systems: causes, consequences, and solutions. Ecology and Society 11(1): 14.

Cumming, G. S., T. H. Morrison, and T. P. Hughes. 2016. New directions for understanding the spatial resilience of socialecological systems. Ecosystems 20(4):649-664. http://dx.doi. org/10.1007/s10021-016-0089-5

Davidson, D. J. 2010. The applicability of the concept of resilience to social systems: some sources of optimism and nagging doubts. Society and Natural Resources 23(12):1135-1149. http://dx.doi. org/10.1080/08941921003652940

Davis, J. S. 2007. Military natures: militarism and the environment. GeoJournal 69(3):131-134. http://dx.doi.org/ https://doi.org/10.1007/s10708-007-9109-5

Duckworth, W., T. Evans, and R. Timmins. 1993. A habitat and wildlife survey of the Xe Piane National Biodiversity Conservation Area. Lao-Swedish Forestry Cooperation Program, Vientiane, Lao PDR.

Ducourtieux, O., J.-R. Laffort, and S. Sacklokham. 2005. Land policy and farming practices in Laos. Development and Change 36(3):499-526. http://dx.doi.org/10.1111/j.0012-155X.2005.00421. $\underline{\mathrm{X}}$

Dwyer, M. B. 2013. Building the politics machine: tools for "resolving" the global land grab. Development and Change 44 (2):309-333. http://dx.doi.org/10.1002/9781118688229.ch6
Dwyer, M. B., and M. L. Ingalls. 2015. REDD++at the crossroads: choices and tradeoffs for 2015-2020 in Laos (Vol. 179). Center for International Forestry Research, Bogor, Indonesia.

Dwyer, M. B., M. L. Ingalls, and I. G. Baird. 2015. The security exception: development and militarization in Laos's protected areas. Geoforum 69:207-217. http://dx.doi.org/10.1016/j. geoforum.2015.11.002

Elkington, B. G., P. Phiapalath, K. Sydara, V. Somsamouth, N. I. Goodsmith, and D. D. Soejarto. 2014. Assessment of the importance of medicinal plants among communities around Khiat Ngong of Southern Laos. Journal of Environmental Biology 35(4):607.

Environmental Investigations Agency (EIA). 2014. Routes of extinction: the corruption and violence destroying Siamese rosewood in the Mekong. Environmental Investigations Agency, London, UK.

Escobar, A. 1998. Whose knowledge, whose nature? Biodiversity, conservation, and the political ecology of social movements. Journal of Political Ecology 5(1):53-82.

Escobar, A. 1999. After nature: steps to an antiessentialist political ecology. Current Anthropology 40(1): 1-30. http://dx.doi. org/10.1086/515799

Fabinyi, M., L. Evans, and S. J. Foale. 2014. Social-ecological systems, social diversity, and power: insights from anthropology and political ecology. Ecology and Society 19(4): 28.

Folke, C. 2006. Resilience: the emergence of a perspective for social-ecological systems analyses. Global Environmental Change 16(3):253-267. http://dx.doi.org/10.1016/j.gloenvcha.2006.04.002

Foucault, M. 1982. The subject and power. Critical Inquiry 8 (4):777-795. http://dx.doi.org/https://doi.org/10.1086/448181

Foucault, M. 2000. Governmentality. Pages 201-222 in M. Foucault, editor. The essential works of Foucault, 1954-1984. The New Press, New York, New York, USA.

Freudenburg, W. R. 2005. Privileged access, privileged accounts: toward a socially structured theory of resources and discourses. Social Forces 84(1):89-114. http://dx.doi.org/10.1353/sof.2005.0096

Fujita, Y., and K. Phanvilay. 2004. Land and forest allocation and its implications for forest management and household livelihoods: comparison of case studies from CBNRM research in central Laos. Paper presented at the Tenth Biennial Conference of the International Association for the Study of Common Property (IASCP), 9-13 August 2004, Oaxaca, Mexico.

Global Facility for Disaster Reduction and Recovery (GFDRR). 2011. Vulnerability, risk reduction and adaptation to climate change: Lao PDR. Climate risk and adaptation country profile. Global Facility for Disaster Reduction and Recovery, The World Bank Group, Washington, D.C., USA.

Government of the Lao People's Democratic Republic (GoL). 1993. Prime Minister Decree 164 on the Establishment of National Forest Reserves.| Government of the Lao People's Democratic Republic, Vientiane, Lao PDR.

Government of the Lao People's Democratic Republic (GoL). 2000. Xe Pian National Biodiversity Conservation Area 
Management Plan. Government of the Lao PDR, with support from the World Bank and Global Environment Facility, Vientiane, Lao PDR.

Government of the Lao People's Democratic Republic (GoL). 2011. Prime Minister Decree 111 on National Defense Strategic Zone. Government of the Lao People's Democratic Republic, Vientiane, Lao PDR.

Gunderson, L. H. 2001. Panarchy: understanding transformations in human and natural systems. Island Press, Washington, D.C., USA.

Guttal, S. 2011. Whose lands? Whose resources? Development 54 (1):91-97. http://dx.doi.org/https://doi.org/10.1057/dev.2010.109

Hansen, M. C., P. V. Potapov, R. Moore, M. Hancher, S. A. Turubanova, A. Tyukavina, D. Thau, S. V. Stehman, S. J. Goetz, T. R. Loveland, and A. Kommareddy. 2013. High-resolution global maps of 21 st-century forest cover change. Science 342 (6160):850-853. http://dx.doi.org/https://doi.org/10.1126/science.1244693

Ingalls, M. L., and M. B. Dwyer. 2016. Missing the forest for the trees? Navigating the trade-offs between mitigation and adaptation under REDD+. Climatic Change 136(2):353-366. http://dx.doi.org/10.1007/s10584-016-1612-6

Ingalls, M. L., and K. Luangsackda. 2009. Dong Hua Sao-Xe Pian corridor profile. Biodiversity Conservation Corridors Initiative, Environmental Operations Centre of the Asian Development Bank, Bangkok, Thailand.

Ingalls, M. L., and R. C. Stedman. 2016. The power problematic: exploring the uncertain terrains of political ecology and the resilience framework. Ecology and Society 21(1): 6. http://dx.doi. org/10.5751/ES-08124-210106

Ireson, C. J., and W. R. Ireson. 1991. Ethnicity and development in Laos. Asian Survey 31(10):920-937. http://dx.doi.org/https:// doi.org/10.2307/2645064

Khmer Times. 2017. Cambodia, Laos Discuss Border Dispute. [online] URL: http://www.khmertimeskh.com/news/35920/cambodia-laos-discuss-border-dispute/

Lao Statistics Bureau (LSB). 2016. Population census of the Lao PDR. Lao Statistics Bureau, Vientiane, Lao PDR.

Lebel, L., J. M. Anderies,B. Campbell, C. Folke, S. HatfieldDodds, T. P. Hughes, and J. Wilson. 2006. Governance and the capacity to manage resilience in regional social-ecological systems. Ecology and Society 11(1): 19.

Lestrelin, G., M. Giordano, and B. Keohavong. 2005. When "conservation" leads to land degradation: lessons from Ban Lak Sip, Laos. Research Report 91, International Water Management Institute, Colombo, Sri Lanka.

MacKinnon, J., and K. MacKinnon. 1986. Review of the protected areas system in the Indo-Malayan realm. International Union for the Conservation of Nature, Gland, Switzerland.

Massey, D. 1999. Space-time, 'science' and the relationship between physical geography and human geography. Transactions of the Institute of British Geographers 24(3):261-276. http://dx. doi.org/https://doi.org/10.1111/j.0020-2754.1999.00261.x
McSweeney, B. 1996. Identity and security: Buzan and the Copenhagen School. Review of International Studies 22 (1):8193.

Meynell P. J., O. Thongsavath, K. Xeuasing, V. Vannalath, and R. Glemet. 2014. Climate vulnerability assessment of Beung Kiat Ngong Ramsar site, Lao PDR. International Union for the Conservation of Nature, Vientiane, Lao PDR.

National Assembly. 2014. Notice to the government to request resurvey and re-delineation of the 3 forest categories. Number 273/ NA, 21 August 2014. National Assembly of the Lao People's Democratic Republic, Vientiane, Lao PDR.

Nelson, D. R., W. N. Adger, and K. Brown. 2007. Adaptation to environmental change: contributions of a resilience framework. Annual Review of Environmental Resources 32:395-419. http://dx. doi.org/10.1146/annurev.energy.32.051807.090348

Oels, A. 2005. Rendering climate change governable: from biopower to advanced liberal government? Journal of Environmental Policy and Planning 7(3):185-207. http://dx.doi. org/https://doi.org/10.1080/15239080500339661

Okereke, C. 2006. Global environmental sustainability: intragenerational equity and conceptions of justice in multilateral environmental regimes. Geoforum 37(5):725-738. http://dx.doi. org/10.1016/i.geoforum.2005.10.005

Pain, A., and S. Levine. 2012. A conceptual analysis of livelihoods and resilience: addressing the "insecurity of agency." Overseas Development Institute, London, UK.

Phelps, J., E. L. Webb, and A. Agrawal. 2010. Does REDD+ threaten to recentralize forest governance. Science 328(5976):312313. http://dx.doi.org/10.1126/science.1187774

Poulsen, M. K., and K. Luanglath. 2005. Projects come, projects go: lessons from participatory monitoring in southern Laos. Biodiversity and Conservation 14)(11):2591-2610. http://dx.doi. org/10.1007/s10531-005-8390-1

Radio Free Asia. 2016. Cambodians attempt to block Lao construction in disputed border area. Radio Free Asia. [online] URL: http://www.rfa.org/english/news/cambodia/cambodiansattempt-to-block-04182016163039.html

Ribot, J. C., and N. L. Peluso. 2003. A theory of access. Rural Sociology 68(2):153-181. http://dx.doi.org/10.1111/j.1549-0831.2003. $\underline{\mathrm{tb} 00133 . \mathrm{x}}$

Ross, H., and F. Berkes. 2013. Community resilience: a rejoinder to Debra J. Davidson. Society and Natural Resources 26(1):2529. http://dx.doi.org/https://doi.org/10.1080/08941920.2012.749769

Salter, R. E., and B. Phanthavong. 1989. Needs and priorities for a protected area system in Lao PDR. Forest Resources Conservation Project, Lao-Swedish Forestry Cooperation Program, Vientiane, Lao PDR.

Scotson, L. 2012. Status of Asiatic black bears and sun bears in Xe Pian national protected area, Lao PDR. International Bear News 21:8-11.

Singh, S. 2013. The socio-economic context of illegal logging and trade of rosewood along the Cambodian-Lao border. Forest Trends Report Series, Forest Trade and Finance, Washington, D.C., USA. 
Spaargaren, G., and A. P. J. Mol. 1992. Sociology, environment, and modernity: ecological modernization as a theory of social change. Society and Natural Resources 5:323-344. http://dx.doi. org/10.1080/08941929209380797

Steinmetz, R. 2004. Gaur (Bos gaurus) and banteng (B. javanicus) in the lowland forest mosaic of Xe Pian Protected Area, Lao PDR: abundance, habitat use, and conservation. Mammalia 68(23):141-157. http://dx.doi.org/https://doi.org/10.1515/mamm.2004.015

Timmins, R. J., T. D. Evans, and J. W. Duckworth. 1993. A wildlife and habitat survey of Xe Pian proposed protected area. International Union for the Conservation of Nature, Wildlife Conservation Society, and Division of Forestry Resource Conservation, Champasak, Lao PDR.

Vandergeest, P. 2003. Land to some tillers: development-induced displacement in Laos. International Social Science Journal 55 (1):47-56. http://dx.doi.org/https://doi.org/10.1111/1468-2451.5501005

Walker, B., C. S. Holling, S. Carpenter, and A. Kinzig. 2004. Resilience, adaptability and transformability in social-ecological systems. Ecology and Society 9(2): 5.

Walker, P. A., and P. E. Peters. 2001. Maps, metaphors, and meanings: boundary struggles and village forest use on private and state land in Malawi. Society and Natural Resources 14 (5):411-424. http://dx.doi.org/10.1080/089419201300122297

Watts, M. 2009. Political ecology. Pages 545-546 in D. R. Gregory, R. Johnston, G. Pratt, M. Watts, and S. Whatmore, editors. The dictionary of human geography. Wiley, London, UK.

Westley, F., O. Tjornbo, L. Schultz, P. Olsson, C. Folke, B. Crona, and O. Bodin. 2013. A theory of transformative agency in linked social-ecological systems. Ecology and Society 18(3): 27.

Wilson, M. A., and R. B. Howarth. 2002. Discourse-based valuation of ecosystem services: establishing fair outcomes through group deliberation. Ecological Economics 41(3):431-443. http://dx.doi.org/10.1016/S0921-8009(02)00092-7

World Wide Fund for Nature (WWF). 1997. Rapid and participatory biodiversity assessments (BIORAP) in Xe Piane $N B C A$. WWF-Thailand Project Office, Burapha Development Consultants, Bangkok, Thailand.

World Wide Fund for Nature (WWF). 2013. Xe Pian REDD++ project design document. World Wide Fund for Nature-Austria and Österreichische Bundesforste (ÖBf, Vientiane, Lao PDR.

Yarrow, M. M., and V. H. Marín. 2007. Toward conceptual cohesiveness: a historical analysis of the theory and utility of ecological boundaries and transition zones. Ecosystems 10 (3):462-476. http://dx.doi.org/10.1007/s10021-007-9036-9

Zimmerer, K. S. 2003. Environmental zonation and mountain agriculture in Peru and Bolivia: socioenvironmental dynamics of overlapping patchworks and agrobiodiversity conservation. Pages 141-169 in K. S. Zimmerer and T. J. Bassett, editors. Political ecology: an integrative approach to geography and environmentdevelopment studies. The Guilford Press, New York, New York, USA. 